\title{
Comparison of Agathis philippinensis resin tapping and collection practices in three selected sites in the Philippines
}

\author{
VIVIAN C. DARACAN", ROSALIE C. MENDOZA, ALFIE M. TORRES, AILEEN A. JARA, \\ RONNIEL D. MANALO, CHELLE HENNESSY R. BATALLONES, RAMON A. RAZAL \\ Department of Forest Products and Paper Science, Wood Science Building, D.M. Lantican Street, College of Forestry and Natural Resources, University \\ of the Philippines Los Baños, College, Laguna 4031, Philippines. Tel./fax.: +63-49-536 3432, `email: vcdaracan@up.edu.ph
}

Manuscript received: 1 August 2020. Revision accepted: 5 November 2020.

\begin{abstract}
Daracan VC, Mendoza RC, Torres AM, Jara AA, Manalo RD, Batallones CHR, Razal RA. 2020. Comparison of Agathis philippinensis resin tapping and collection practices in three selected sites in the Philippines. Biodiversitas 21: 5595-5604. This study documented and compared almaciga (Agathis philippinensis Warb.) resin tapping and collection practices in three sites namely Mt. Hamiguitan, Governor Generoso, Davao Oriental; Mt. Mantalingahan, Brooke's Point, southern Palawan; and Puerto Princesa Subterranean River National Park, Marufinas, central Palawan. Resin tappers, mostly male belonging to a local organization, were interviewed, and tapping sites were visited. Tapping and collecting A. philippinensis resin is one of the supplemental income sources of the respondents from the three sites. Market influences, and how tappers learned the trade could partly explain the similarities and differences in tapping practices. Discrepancies in selecting trees to be tapped, tools used, type of incisions made on the bark, and how resin was harvested were noted. Differences in resin appearance across sites were observed, and the existence of uncollected and wasted resins clinging to trees or sprawling at its base was found in all sites. Removing dirt from the portion of the stem to be tapped, covering the bark incision with plastic for protection, and contriving handmade resin baskets from plant parts available in the site were some practices found to be worth replicating. On the other hand, there were damaged or dying trees due to the intensity of tapping, the lack of tapping skills, and limited attention given to the health of trees. There is a need for strengthening tappers' organizations for increased bargaining power to secure better resin price and policy support to prioritize indigenous peoples in tapping into their ancestral domain. Tappers can benefit from cross-visits and other learning opportunities for sharing lessons and experiences to improve tapping practices for better resin quality and higher prices.
\end{abstract}

Keywords: Agathis philippinensis, almaciga, indigenous knowledge, local tappers, resin yield, supply chain

\section{INTRODUCTION}

Almaciga (Agathis philippinensis Warb.) is an indigenous Philippine softwood species belonging to the family Araucariaceae. Its height reaches $60 \mathrm{~m}$ and diameter at breast height can reach up to $300 \mathrm{~cm}$. It thrives in mountainous forests throughout the Philippines particularly in the provinces of Cagayan, Rizal, Isabela, Benguet, Abra, Zambales, Nueva Ecija, Bataan, Quezon, Polilio, Aurora, Mindoro, Camarines, Albay, Sorsogon, Calayaan Island, Sibuyan, Negros, Samar, Palawan, Misamis, Davao, and Zamboanga (ERDB-DENR 2013). A. philippinensis is the main source of resin commercially known as "Manila Copal," considered as the country's most important chemical non-timber forest products (NTFPs). Manila copal comes in the form of ground or fossil resin, or as surface or tapped resin. Fossil resin is the amber-colored exudation from the roots, which is obtained by digging into the ground where the plant once grew, whereas surface resin is extracted by tapping living A. philippinensis trees. The resin is mainly used as a component of varnishes (Frezza et al. 2020). In addition, resins, in general, are used in torches, embalming chemicals, waterproofing and caulking ships, incense, paints, and medicines, a major portion of the resins are also used as food additives, paint, lacquer, paper, cosmetics, food, pharmaceutical and chemical industries (Sharma et al. 2018). In southern Palawan, the resin of A. philippinensis is also used as an adhesive for making native baskets (Guerrero C 2020, pers. com).

At the core of the supply chain for A. philippinensis resin are the tappers who are mostly indigenous peoples (IPs) or members of indigenous cultural communities (ICCs). Tapping A. philippinensis trees for resin has become one of the major livelihoods of many indigenous groups in the country, especially in Palawan, Davao Oriental, and northeastern Luzon. A. philippinensis trees remain relatively abundant in the identified study sites, namely the municipality of Governor Generoso, Davao Oriental in Mindanao, in Mt. Mantalingahan in Brooke's Point, southern Palawan, and the hinterlands of Puerto Princesa City, in the central part of Palawan. In Gov. Generoso, there are a little over 100,000 standing $A$. philippinensis trees in about a hundred hectares of stand (Mordeno 2019). Since 2007, the local government unit of Gov. Generoso has been supporting tappers belonging to the Mandaya and Manobo Lumad tribes and some Bisaya tappers through the "Biodiversity Partnership Project." The Gov. Generoso tappers are organized into an association called Lumad Almaciga Tappers Association of Governor Generoso (LATAGG). 
Meanwhile, indigenous communities in Palawan who are engaged in tapping include the Pala'wan and Tagbanua. The Pala'wan is one of the oldest tribes in the Philippines (Perez 2014). In Brooke's Point, the Pala'wan tappers, who are also members of an existing communityowned cooperative known as Samahan ng mga Pala'wano sa Amas Brooke's Point (SBABP), have been tapping A. philippinensis trees for years. Since the 1990s, SBABP has been managing tapping operations, from the inventory of the resin-producing trees up to trading of the resin. In Marufinas, Puerto Princesa City, the community organizers and the male members of the Samahang Pagkakaisa ng mga Katutubong Tagbanua ng Marufinas (SPKTM) are engaged in tapping A. philippinensis trees.

This paper describes and compares the resin tapping and collection practices in the three resin tapping communities. Although the market for A. philippinensis resin exists and there had been various efforts towards industry development, information on the production chain is still limited. There is so much to be learned by reaching out to the communities as tapping practices are mostly traditional and location specific. An understanding of the local practices is vital to enable sustainable resource management, biodiversity protection, and the development of a more efficient value chain. Possible interventions and recommendations are presented to enhance local practices for more efficient extraction and to contribute to the further development of the resin industry.

\section{MATERIALS AND METHODS}

For the key informant interviews (KIIs) and the focus group discussions (FGDs), a semi-structured interview schedule was prepared. The interview questions were designed to elicit information on the profile of the tappers, their tapping and collection practices, which include activities done before, during, and after tapping, how they learned to do tapping, the various tools they use, the frequency of tapping and collection, as well as problems and challenges encountered during tapping, collection and marketing the resins.

As mentioned, the target communities are the tappers in (a) Gov. Generoso, Davao Oriental, (b) Brooke's Point, Palawan, and (c) Marufinas, Puerto Princesa City, Palawan. Permits were obtained from various local authorities to be able to conduct the interviews and to document the resin tapping and collection practices. In Gov. Generoso, letters were sent to the Office of the Municipal Mayor to be able to visit and conduct the data gathering work. The courtesy call, site reconnaissance, and interview with tappers and representatives of the local government of Gov. Generoso were conducted on April 4-6, 2019. The respondents who were interviewed in Gov. Generoso were residents of six barangays namely Oregon, Sergio Osmena, Surop, Tandang Sora, Tiblawan, and Upper Tibanban, while the former Mayor (now Vice Mayor) and the Municipal Tourism Officer served as respondents for the focus group discussion. The project team was assisted by the local government in identifying and bringing to the town center the tappers who served as interview respondents.

In conducting the study in Palawan, a gratuitous permit had to be obtained based on the requirements of the Palawan Council for Sustainable Development (PCSD), which entailed submission of a letter of intent, payment of application fee, submission of a copy of the research proposal and a Memorandum of Understanding that the results will be shared with PCSD upon project completion. Separate presentations to the respective Protected Area Management Boards (PAMBs) that have jurisdiction over the study sites were also done to secure the PAMB clearance. The community also had to be consulted to provide the Free Prior Informed Consent (FPIC) stating their willingness to allow the research team to conduct the study in their sites. In Brooke's Point, the team was assisted by the Nagkakaisang mga Tribu ng Palawan (NATRIPAL), a non-government organization composed of different tribal organizations in Palawan, in bringing the tappers to a community house in Barangay Amas in the lowland for the KIIs and FGDs. The tappers reside in the upland areas of Barangay Amas and Saraza in Mt. Mantalingahan. For Barangay Marufinas in Puerto Princesa City, the project team was assisted by the Office of the Protected Area Superintendent of the Puerto Princesa Underground River in bringing the tappers to the Puerto Princesa City Office for the interviews. Travel to Puerto Princesa City and Brooke's Point for the conduct of respective focus group discussions were held from April 29 to May 2, 2019.

Actual field observations were later done to validate information collected from the interviews and FGDs, observe tapping, and assess the status of the $A$. philippinensis trees that were tapped in the different sites. Gov. Generoso was revisited on June 24-28, 2019 when actual resin tapping activities in barangays Tandang Sora, Tiblawan, and Upper Tibanban in Mt. Hamiguitan were observed. For Palawan, field observations were conducted on September 8-15, 2019 in resin tapping sites in Mt. Mantalingahan in Brooke's Point. The field visit to Puerto Princesa Subterranean River National Park in Barangay Marufinas was done on November 9-15, 2019. The field visits to the different sites involved various forms of transport and required significant trekking over long distances. Going to Marufinas also entailed traversing a portion of the West Philippine Sea by boat, which is done at a time of the year when the seawater is relatively calm.

Altogether, several relevant actors involved in the $A$. philippinensis resin tapping and collection practices were interviewed. Photo documentation of the tapping practices, tools used, and of the tapped trees was done. Team meetings were conducted to compare the tapping and collection practices from the different sites and evaluate the information gathered. This led to the identification of gaps and problems and the formulation of interventions and recommendations for the improvement of existing practices. 


\section{RESULTS AND DISCUSSION}

\section{Profile of the respondents}

A total of 31 respondents from Gov. Generoso, 24 from Brooke's Point, and 20 from Puerto Princesa City were interviewed. Their profile is shown in Table 1. In the municipality of Gov. Generoso, the interviewed tappers belong to the Lumad Almaciga Tappers Association of Gov. Generoso or LATAGG. The ages of the tappers are from 15-70 years old. Because A. philippinensis trees were found to be abundant in the municipality, the local government unit of Gov. Generoso introduced the tapping of the trees to help in the livelihood of the upland communities who depend mostly on planting crops, livestock, and fishing. They sought help from the Forest Products Research and Development Institute-Department of Science and Technology (FPRDI-DOST) to train the community members on the proper tapping of the $A$. philippinensis trees. Resin collection is done from $A$. philippinensis trees growing within their barangay as assigned to them by a kapatas, the foreman selected by the community tasked to hire tappers and or supervise an $A$. philippinensis stand. For each tapper, the number of trees that could be tapped ranges from 15 to more than 700 trees. There is strong local government support for sustaining tapping as a livelihood, evident in the establishment of a nursery designed to nurture A. philippinensis seedlings for transplanting in the forest.

In Brooke's Point, the Pala'wan tappers are organized into the Samahan ng mga Pala'wano sa Amas Brooke's Point (SBABP). The tappers, mostly male, are between 18 to 60 years old, the eldest of whom has been tapping $A$. philippinensis trees for most of his life. The number of trees that each tapper can claim ranges from four to more than 100 trees. Young tappers acquired their knowledge and skills in tapping the resin producing trees from their ancestors. For most of them, farming, craft-making, and resin tapping remain to be their source of income.

The ages of the tappers from Marufinas in Puerto Princesa City ranged from 19-45 years old. These tappers learned tapping from their ancestors, with no formal training. Their primary livelihood consists of farming and fishing. Tappers, who belong to the Tagbanua tribe, are members of Samahang Pagkakaisa ng mga Katutubong Tagbanua ng Marufinas (SPKTM). The organization also facilitates the trade of goods and services within the barangay. In both sites in Palawan, the parents pass on a certain number of trees to their children or nearest kin. Each can lay claim to tap from five to more than 20 trees.

Non-tribal individuals from nearby villages may be given the right to cultivate and tap A. philippinensis trees. In Gov. Generoso, the decision rests on the resident tappers per barangay. In Upper Tibanban, resident tappers do not allow tappers from outside the barangay to tap trees within their area. In Palawan, non-tribal individuals who marry members of indigenous communities may be allowed to tap after submitting papers for the barangay council's permission, albeit it is a practice that is forbidden according to indigenous law (Olave 2020, pers. com).

According to Sopsop and Buot (2011), collection of rattan poles and $A$. philippinensis resins, the two most common commercial non-timber forest products, remains intense and considered as the main source of income among the IPs in Palawan. Some Palawan resin tappers are also rattan gatherers. They utilize it in handicraft making such as baskets and mats. Some gather rattan for improvising containers for collecting and transporting the resin.

The observed practices from the pre-tapping up to the post-tapping of $A$. philippinensis in the three sites are discussed in the succeeding sections and summarized in Table 3.

Table 1. Profile of respondents from the three sites in Davao Oriental and Palawan, Philippines

\begin{tabular}{|c|c|c|c|}
\hline \multirow[b]{2}{*}{ Demographic profile } & \multicolumn{3}{|c|}{ Study sites } \\
\hline & $\begin{array}{l}\text { Mt. Hamiguitan, } \\
\text { Governor Generoso, } \\
\text { Davao Oriental }\end{array}$ & $\begin{array}{l}\text { Mt. Mantalingahan, } \\
\text { Brooke's Point, } \\
\text { Palawan }\end{array}$ & $\begin{array}{c}\text { Puerto Princesa } \\
\text { Subterranean River National } \\
\text { Park, Puerto Princesa City, } \\
\text { Palawan }\end{array}$ \\
\hline Age & $15-70$ & $18-60$ & $19-45$ \\
\hline $\begin{array}{l}\text { Gender involved in the tapping } \\
\text { and collection activities }\end{array}$ & Mostly males & Mostly males & Mostly males \\
\hline Residence (Sitio/Barangay) & $\begin{array}{l}\text { Barangays Oregon, Sergio } \\
\text { Osmena, Surop, Tandang } \\
\text { Sora, Tiblawan, Upper } \\
\text { Tibanban }\end{array}$ & $\begin{array}{l}\text { Sitios Malia and Macaguaay in } \\
\text { Barangay Amas } \\
\text { Sitios Banton, Candis, Neltikan, } \\
\text { and Kalwe in Barangay Saraza }\end{array}$ & Barangay Marufinas \\
\hline Main source of income & Farming and fishing & Farming, craft-making & Farming and fishing \\
\hline $\begin{array}{l}\text { How knowledge in tapping was } \\
\text { acquired }\end{array}$ & $\begin{array}{l}\text { Learned through } \\
\text { training/seminars }\end{array}$ & $\begin{array}{l}\text { Inherited/acquired from } \\
\text { parents/relatives (Indigenous } \\
\text { knowledge) }\end{array}$ & $\begin{array}{l}\text { Inherited/acquired from } \\
\text { parents/relatives (Indigenous } \\
\text { knowledge) or learned from } \\
\text { co-tapper }\end{array}$ \\
\hline $\begin{array}{l}\text { Number of } A . \text { philippinensis } \\
\text { trees being tapped }\end{array}$ & $15-700+$ & $4-100+$ & $5-20+$ \\
\hline Association/Cooperative & $\begin{array}{l}\text { Lumad Almaciga Tappers } \\
\text { Association of Gov. } \\
\text { Generoso (LATAGG) }\end{array}$ & $\begin{array}{l}\text { Samahan ng mga Pala'wano sa } \\
\text { Amas Brooke's Point (SBABP) }\end{array}$ & $\begin{array}{l}\text { Samahang Pagkakaisa ng mga } \\
\text { Katutubong Tagbanua ng } \\
\text { Marufinas (SPKTM) }\end{array}$ \\
\hline
\end{tabular}


Table 3. Summary of the resin tapping and collection practices observed in Davao Oriental and Palawan, Philippines

\begin{tabular}{|c|c|c|c|}
\hline \multirow[b]{2}{*}{ Tapping stages } & \multicolumn{3}{|c|}{ Study sites } \\
\hline & $\begin{array}{l}\text { Governor Generoso, } \\
\text { Davao Oriental }\end{array}$ & $\begin{array}{l}\text { Brooke's Point, } \\
\text { Palawan }\end{array}$ & $\begin{array}{c}\text { Puerto Princesa City, } \\
\text { Palawan }\end{array}$ \\
\hline Pre-tapping activities & \multicolumn{2}{|c|}{ Factors considered/practices employed } & \\
\hline $\begin{array}{l}\text { Selection of the } A \text {. } \\
\text { philippinensis tree to be } \\
\text { tapped }\end{array}$ & $\begin{array}{l}\text { Bark structure, tree location, } \\
\text { crown density, tree dbh }\end{array}$ & Resin color, tree dbh & Bark structure, tree dbh \\
\hline $\begin{array}{l}\text { Cleaning of the tree and } \\
\text { immediate surroundings }\end{array}$ & $\begin{array}{l}\text { Most tappers clean the tree, } \\
\text { scrape off the bark and clear } \\
\text { the immediate surroundings } \\
\text { where the resin will flow }\end{array}$ & $\begin{array}{l}\text { Only the older tappers perform } \\
\text { this activity }\end{array}$ & Not practiced \\
\hline Actual tapping activities & \multicolumn{2}{|c|}{ Factors considered/practices employed } & \\
\hline Choice of tapping tools & Bolo/machete, branchwood & Bolo/machete, branchwood & Bolo/machete, branchwood \\
\hline $\begin{array}{l}\text { Choice of cutting shape and } \\
\text { dimensions }\end{array}$ & $\begin{array}{l}\text { Rectangular cut } \\
5 \mathrm{~cm} \times 30 \mathrm{~cm} \\
10 \mathrm{~cm} \times 30 \mathrm{~cm} \\
\text { No specific depth of cut }\end{array}$ & $\begin{array}{l}\text { Diamond-shaped, } \\
\text { Triangle shaped incision } \\
6 \mathrm{~cm} \times 6 \mathrm{~cm} \\
\text { Quadrilateral method } \\
\text { No specific dimensions } \\
\text { No specific depth of cut }\end{array}$ & $\begin{array}{l}\text { Rectangular cut with no } \\
\text { specific dimensions } \\
\text { No specific depth of cut }\end{array}$ \\
\hline Rechipping & $\begin{array}{l}\text { Creating a thin cut just above } \\
\text { the previously made cut; the } \\
\text { schedule is dependent on the } \\
\text { time/choice of tappers (once a } \\
\text { week, once a month, twice a } \\
\text { month, once every three } \\
\text { months, etc.) }\end{array}$ & $\begin{array}{l}\text { Cutting the original wound or } \\
\text { creating new cuts above the } \\
\text { previous one depending on resin } \\
\text { flow, usually done } 15 \text { days }\end{array}$ & $\begin{array}{l}\text { Creating a continuous cut } \\
\text { above the previous cut } \\
\text { following its shape/resin } \\
\text { flow, usually done once a } \\
\text { month }\end{array}$ \\
\hline $\begin{array}{l}\text { Wrapping/sealing of tapped } \\
\text { portion using plastic }\end{array}$ & $\begin{array}{l}\text { Some tappers wrap and seal } A \text {. } \\
\text { philippinensis resin on the tree } \\
\text { itself with clear plastic attached } \\
\text { to the tapped portion using } \\
\text { small wooden pegs }\end{array}$ & Not practiced & Not practiced \\
\hline \multicolumn{4}{|l|}{ Post tapping activities } \\
\hline \multirow{2}{*}{ Collection of resin } & Tappers use bolo & Tappers use bolo & Tappers use bolo \\
\hline & $\begin{array}{l}\text { Some tappers still use plastic to } \\
\text { contain resin } \\
\text { Some use plastic bags or sacks } \\
\text { to contain resin }\end{array}$ & $\begin{array}{l}\text { Tappers use a kayobong to } \\
\text { contain resin and kiba to transport } \\
\text { the resin }\end{array}$ & $\begin{array}{l}\text { Tappers use a sarad to } \\
\text { contain resin and rarong to } \\
\text { transport the resin }\end{array}$ \\
\hline Cleaning of resin & $\begin{array}{l}\text { Tappers clean their resins using } \\
\text { bolo to remove dirt and other } \\
\text { impurities }\end{array}$ & $\begin{array}{l}\text { Tappers clean their resins using } \\
\text { bolo to remove dirt and other } \\
\text { impurities }\end{array}$ & Not practiced \\
\hline \multirow[t]{4}{*}{ Sorting of resin } & $\begin{array}{l}\text { Local buyers perform solubility } \\
\text { test using lacquer thinner to } \\
\text { determine the resin class }\end{array}$ & $\begin{array}{l}\text { Classifier weighs the resin and } \\
\text { sorts the resin into tipak, class a } \\
\text { and class b }\end{array}$ & Not practiced \\
\hline & Price of resin: & Price of resin: & Price of resin: \\
\hline & PhP 20/kg (USD 0.39) & Tipak (PhP 30/kg or USD 0.59) & $\mathrm{PhP}$ 18-20/kg (USD 0.36- \\
\hline & & $\begin{array}{l}\text { Class a }(\mathrm{PhP} 28 / \mathrm{kg} \text { or USD } 0.55) \\
\text { Class b }(\mathrm{PhP} 10 / \mathrm{kg} \text { or USD } 0.20)\end{array}$ & $0.40)$ \\
\hline Storing of resin & $\begin{array}{l}\text { Resins are stored in a } \\
\text { designated area }\end{array}$ & $\begin{array}{l}\text { Resins are stored in a designated } \\
\text { area }\end{array}$ & $\begin{array}{l}\text { No storage area for collected } \\
\text { resin }\end{array}$ \\
\hline
\end{tabular}

\section{Observations on resin tapping and collection practices Pre-tapping activities \\ Selection of Agathis philippinensis trees to be tapped}

Tappers from the three sites have different considerations in selecting the tree to be tapped. Tappers from Gov. Generoso classify their A. philippinensis trees as almaciga babae and almaciga lalaki, meaning female and male trees, respectively. According to the tappers, almaciga babae and almaciga lalaki differ in the color of the inner bark, where almaciga babae has white inner bark while almaciga lalaki has reddish inner bark. In terms of resin yield, the tappers observed that almaciga babae produced more resin than almaciga lalaki. The tappers also consider the location of the tree and its crown density in the tree selection. They choose the tree with a higher crown spread because they believe it would exude more resin. They do not tap trees that are in downhill areas for safety and practical reasons. Some studies reported a positive relationship between the crown ratio and resin flow of pine species (Davis et al. 2012; Rodríguez-García et al. 2014; 
Lai et al. 2017; Seyfullah et al. 2018) emphasizing that trees with larger crown biomass would be richer in carbohydrates available for defense (resin production and resin duct formation). Lai et al. (2017) explained that the accumulation of greater carbon surpluses by trees with larger crown sizes makes possible the shift of carbohydrate allocation from growth to defense, leading to more production of resin.

Palawan tappers have fewer considerations in selecting the A. philippinensis trees to be tapped. Tappers from Brooke's Point classify A. philippinensis trees based on resin color - puti for those trees with white resin and bunga-bunga for those with red resin, also known as "kemanga" among the Pala'wan. The tappers from Marufinas in Puerto Princesa, on the other hand, select $A$. philippinensis trees based on bark characteristics such as thickness and hardness. They believe that thin and hard bark which cannot easily be removed or peeled off from the trunk will produce low amounts of resin, while thick and soft barks will give high resin yield. This local practice is supported by different scientific studies. It was reported that there is a positive correlation of bark thickness with resin production not only in A. philippinensis (FAO 1995) but also in other resin-producing species like Pinus merkusii (Susilowati and Rachmat 2018) and lacquerproducing Toxicodendron vernicifluum varieties (Zhao et al. 2013). There is also a study which found that bark thickness is directly related to tree protection mechanisms against external mechanical disturbances such as wind that can damage resin ducts, thus affecting resin yield (Susilowati and Rachmat 2018). The study of Tolera et al. (2013) on the inner bark anatomy of Boswellia papyrifera can also explain why thicker bark is preferred in tapping. According to this study, inner bark can be segmented into three zones: intact, partially dilated, and highly dilated zones. More resin canals are present in the partially dilated and intact zones which occupy the bulk of inner bark. The thicker the bark, the larger area being occupied by these resin canal-rich zones.

Another factor that was considered by tappers in the three sites is the diameter at breast height (dbh) of the tree. Most Palawan tappers consider trees with a dbh of $>45 \mathrm{~cm}$ as suitable for tapping (Razal et al. 2013). They estimate the dbh using commonly available measuring units like dangkal (length of a stretched-out hand from the tip of the pinky finger to the tip of the thumb) and dipa (length of both arms stretched out). Some tappers use car tire, electrical post, or drum container to estimate dbh. Meanwhile, tappers in Gov. Generoso follow the FPRDIDOST guidelines and select trees with at least $40 \mathrm{~cm}$ dbh. They measure the tree dbh using a steel tape which they were trained to use.. However, in all the sites, some tappers do not strictly follow this dbh requirement and tap trees with dbh smaller than the suggested range. During the site visit in Marufinas, the team encountered a small tree that was already subjected to tapping (Figure 1). The use of a calibrated rope for dbh measurement is recommended by the study team especially in Palawan to avoid underestimation of the tree dbh and the tapping of trees smaller than the prescribed dbh.

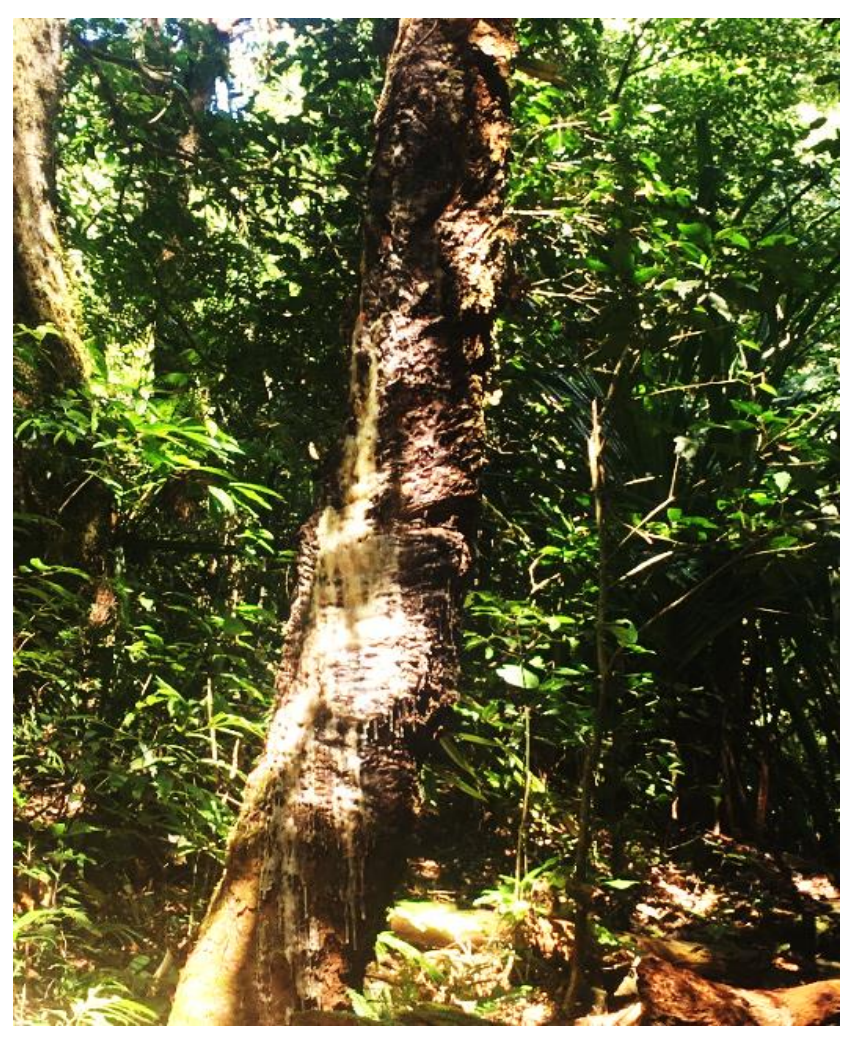

Figure 1. Tapped Agathis philippinensis tree with diameter at breast height below $40 \mathrm{~cm}$

The belief of tappers that tree size affects resin yield is supported by several studies. Based on the FPRDI-DOST guidelines, tapping should be done only on trees with a dbh of at least $40 \mathrm{~cm}$ (Ella and Tongacan 1992). It is recommended to avoid tapping A. philippinensis trees with $60 \mathrm{~cm} \mathrm{dbh}$ and larger. Similarly, Hadiyane et al. (2015) reported that the production of resin from Pinus merkusii was affected by tree diameter. The average resin production of diameter class $38-40 \mathrm{~cm}$ exhibited higher resin yield than the average values of the other smaller diameter classes within the range of $30-38 \mathrm{~cm}$ (Hadiyane et al. 2015). Based on the findings in these studies, it was recommended that only $A$. philippinensis trees with at least $40-60 \mathrm{~cm}$ dbh should be tapped. Ella (2000) pointed out that with a larger bark surface and heavier crown, a bigger tree would produce more resin than a smaller one. Ella further stated that resin yield increased with increasing diameters up to $60 \mathrm{~cm}$, and then decreased at higher diameter classes.

Based on observations from the three sites, tappers used different criteria to determine if a tree would give low or high resin yield. They relied on the physical features of the tree or of the resin itself. Further research on which varieties of $A$. philippinensis could produce higher resin yield is being conducted. This will aid in the proper identification of trees to be tapped and could help avoid mistrials and reduce the number of trees that are damaged or killed. 


\section{Cleaning of the tree and immediate surroundings}

Another pre-tapping activity that is done is cleaning the A. philippinensis tree and its immediate surroundings. This includes weeding and removal of pocked-mark barks, fallen leaves, and dirt within the immediate area of the standing tree to avoid the accumulation of impurities when the resin flows from the cut. This is also done to avoid insect attacks such as by ants and termites that may eventually cause deterioration of the tree, leading to lesser resin flow (Razal et al. 2013). Tappers from Gov. Generoso and the older tappers from Brooke's Point perform this activity, and this should be replicated by the younger tappers from Brooke's Point and Puerto Princesa City. It was observed that the resin collected by tappers who cleaned the trees have lesser impurities embedded in the resin. FAO (1995) emphasized that harvesting, cleaning, and handling practices of resins have the greatest influence on the quality of the product, and hence, every effort should be made to improve these activities. Moreover, clean resin, which is considered good quality resin by buyers and processing companies, is more sought after and commands higher prices in the market. Impurities embedded in the resin lower its price, therefore, decreasing the benefits that the tappers can get from it. Clean resin also has a higher grade based on the system of grading developed by FPRDI-DOST (Ella and Tongacan 1992).

\section{Actual tapping activities}

\section{Choice of tapping tools}

Tappers from the three study sites use similar tools in tapping, like bolo or machete to make incisions on the bark of the tree and any heavy piece of wood, usually a fallen branch which is available in the area to serve as a mallet. With assistance from the government, a tapping tool consisting of a $17 \mathrm{~cm}$-long knife with a curved blade and a special tip for cutting, costing around one hundred fifty pesos (Figure 2) was developed by Gov. Generoso tappers. However, due to the difficulty in using this knife for making a cut on the bark of A. philippinensis, most of the tappers reverted to the use of bolo as their tapping tool. The use of a bolo as a tapping tool in Palawan was previously reported by Razal et al. (2013). Excessive or deep cuts penetrating the cambium was observed in the field. This is due to the uncontrolled cut depth caused by the bolo. Similarly, it was reported that deeply tapped and "overtapped" A. philippinensis trees were found in Cleopatra's Needle Critical Habitat $(\mathrm{CNCH})$ in Palawan. Batak, one of the indigenous people's groups in $\mathrm{CNCH}$, used machete as their main tapping tool (Vermeer et al. 2017). The cambium is penetrated during tapping due to the uncontrolled use of the tool in removing the bark of the tree. Batak tappers shifted from using tapping knives to machete as their tapping tool since the former is too expensive for them to buy (Vermeer et al. 2017). For these reasons, the use of a wood chisel, a tool with flat and wide cutting edge instead of bolo is recommended for tapping. It would be easier to use and control with the help of a wooden mallet. Hence, its use is suggested to inexperienced and beginner tappers.

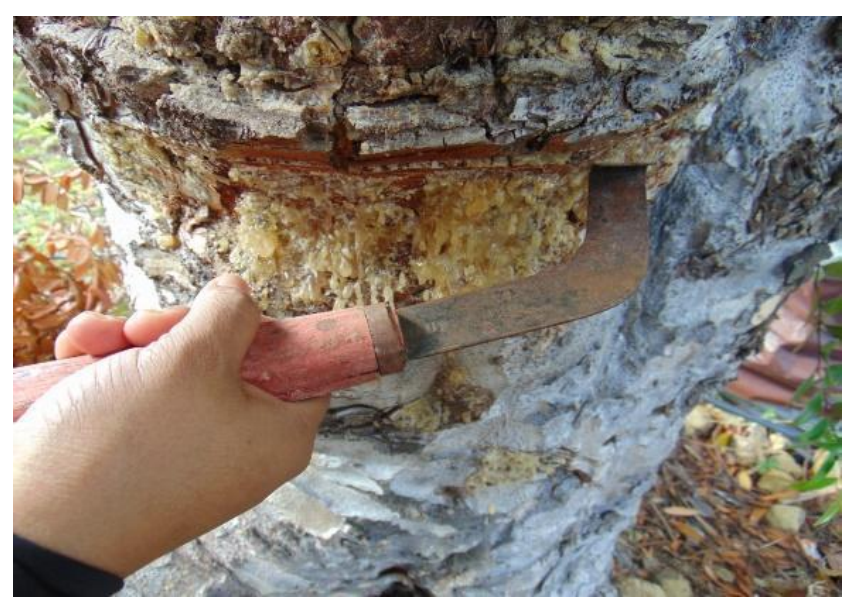

Figure 2. Specialized tapping knife developed for Gov. Generoso tappers

\section{Choice of bark incision shape and dimensions}

The tappers from the three sites make different incision or wound shapes and dimensions on the bark of $A$. philippinensis trees (Figure 3). Gov. Generoso tappers make rectangular cuts with a width of $30 \mathrm{~cm}$ and height of 5 or $10 \mathrm{~cm}$. On the other hand, tappers from Brooke's Point have more varied tapping techniques. Older tappers make diamond- and triangular-shaped wounds as described by Razal et al. (2013), with each side measuring approximately $6 \mathrm{~cm}$, as well as quadrilateral shapes, while others just tap the trees and form no particular size nor shape of the wound. However, according to Guerrero (pers. comm., 2020), tappers in Brooke's Point would initially make a rectangular cut, but the subsequent maintenance tapping, called "ipat" or "pegipat," is in triangular form as the tappers believed that it is the best way to get the "tipak" high-grade resin in large sizes. Resin from an incision that is spread could easily fall, break and would be full of impurities.

In Marufinas, Puerto Princesa City, tappers make rectangular cuts with no specific dimensions. Slanting cuts were also employed by Palawan tappers, which extend to greater than $2 / 3$ of the circumference of the tree (Razal et al. 2013). The data on the two-day resin yield gathered from the field (Table 2) shows that the difference in the cutting shape and dimension among the three sites is statistically significant (with $\mathrm{p}=0.038$ and treatment mean=4.20). The rectangular cut, which was introduced by FPRDI-DOST to Gov. Generoso tappers yields higher resin compared to the triangular and quadrilateral wound shapes practiced in Brooke's Point. In the FPRDI-DOST guidelines on the proper $A$. philippinensis resin tapping techniques, horizontal cut 1 to $2 \mathrm{~cm}$ wide and $30 \mathrm{~cm}$ long using a sharp knife or bolo is recommended (Ella and Tongacan 1992). However, the comparison of resin yield should be taken with precaution since the number ( 3 per type of cut) of trees is limited and the yield values were obtained only for 2 days of tapping, which were done on different dates in different sites. In the study of Seyfullah et al. (2018), it was mentioned that the amount of resin secreted appeared to be related to the size of the injury. 
Table 2. Resin yield of Agathis philippinensis trees from the three sites after 2 days of tapping

\begin{tabular}{|c|c|c|c|c|}
\hline \multirow{3}{*}{ Sap tapping } & \multicolumn{4}{|c|}{ Resin yield (g) } \\
\hline & \multicolumn{2}{|c|}{$\begin{array}{c}\text { Brooke's Point, } \\
\text { Palawan }\end{array}$} & \multirow{2}{*}{$\begin{array}{l}\text { Governor Generoso, } \\
\text { Davao Oriental } \\
\text { Rectangular method }\end{array}$} & \multirow{2}{*}{$\begin{array}{c}\text { Puerto Princesa City, } \\
\text { Palawan } \\
\text { Rectangular method } \\
\end{array}$} \\
\hline & Triangular-shaped & Quadrilateral method & & \\
\hline $1^{\mathrm{st}}$ & 0.8698 & 0.5183 & 3.7867 & 6.4829 \\
\hline $2^{\text {nd }}$ & 2.8177 & 4.3546 & 9.2879 & 4.4721 \\
\hline $3^{\text {rd }}$ & 1.1647 & 1.4215 & 7.3382 & 3.3574 \\
\hline Average & $1.6174^{\mathrm{a}}$ & $2.0981^{\mathrm{a}}$ & $6.8043^{b}$ & $5.4775^{b}$ \\
\hline
\end{tabular}

Note: Means that do not share a letter are significantly different

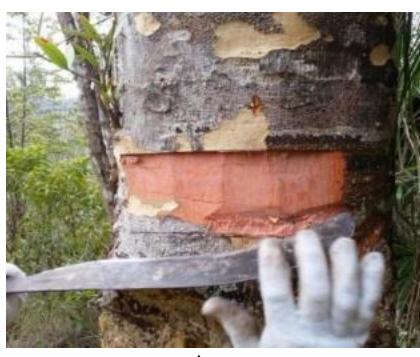

A

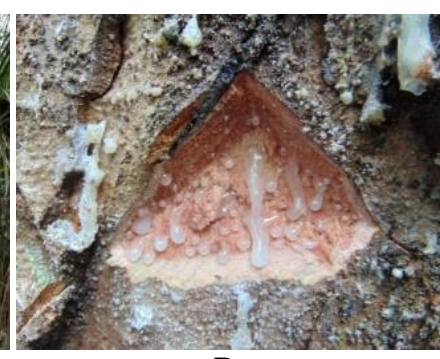

B

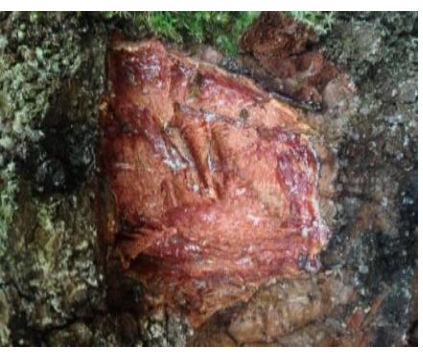

C

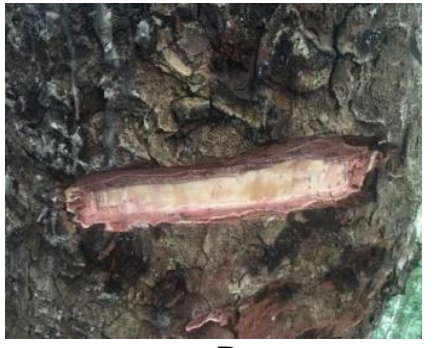

D

Figure 3. Tapping incisions made on the bark of Agathis philippinensis trees by tappers in (A) Governor Generoso, (B \& C) Brooke's Point, Palawan and (D) Marufinas, Puerto Princesa City, Palawan, Philippines

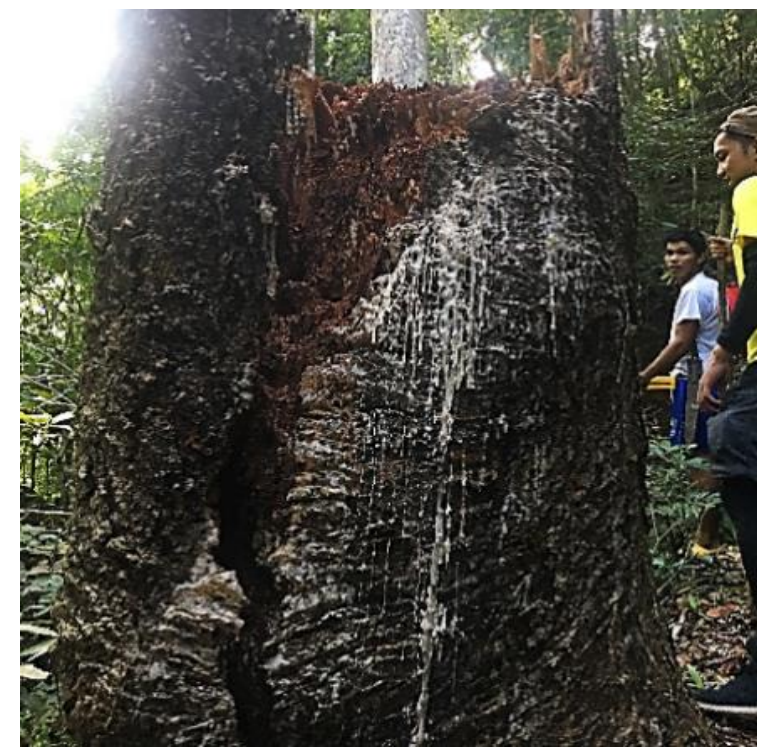

Figure 4. Dead Agathis philippinensis tree in Marufinas, Puerto Princesa City, Palawan, Philippines

It was also observed during the site visits that the depth of cut depended on the knowledge and skills of the tappers. In general, the tappers do not have a specific protocol for the depth of cut, and most of the tappers still make wide and deep cuts into the tree. In Puerto Princesa City, the team encountered dead A. philippinensis trees (Figure 4) which died due to overtapping, based on the tappers' own account. Previous studies stressed the importance of depth of cut in tapping trees for resin production. Williams et al. (2017) cited that radial growth is not possible anymore on the tapped sides of the trunk if the cambium is damaged mechanically. While the removal of woody tissue may not affect tree survival due to the anatomical and chemical defenses of conifer bark against stem infesting insects and pathogens (Krokene 2015), it is critical that the removal of woody tissue is controlled and does not damage the cambium since the formation of new cells, healing, as well as the vulnerability to attacks by decay agents, depend on this tree layer (Ella and Tongacan 1992).

\section{Rechipping}

With rechipping, the resin that accumulates around the bark incision is removed and a new cut (about $3 \mathrm{~cm}$ of bark) is added above the wound to increase resin flow (Vermeer et al. 2017). In Gov. Generoso, rechipping is normally done by creating a thin cut just above the previous cut. When to do rechipping is the tappers' decision, as tappers claimed to perform it once a week, once a month, twice a month, once every three months, etc.) Tappers also allow the resin to harden before collection and rechipping. Brooke's Point tappers employ various methods of rechipping such as making a new wound with the same dimensions above the previous wound, or cutting the upper portion of the original wound, enlarging the original bark opening. Normally, they do rechipping after 15 days. Rechipping by tappers in Marufinas is done just above the previous cut, usually once a month. However, for both sites in Palawan, some previously tapped $A$. philippinensis trees were not regularly rechipped. This is true of the trees that belong to tappers who have other sources of income. Some A. philippinensis trees had numerous uncollected small and discolored lumps of resins that remain attached to the bark or stem. The rechipping practices by Gov. Generoso tappers, in which a thin cut just above the previously made cut is made, can be replicated by the Palawan tappers to avoid damaging the cambium. The depth of the new cut can be controlled to lessen the injury to the tree. According to Samanta et al. 
(2016), repeated wounding is needed at the right season to maximize Commiphora wightii (guggal) resin yield. Frequent rechipping is also believed to increase the flow rate of resin, although it reduces the purity of the exuded product due to the presence of chips of bark, wood, and foreign materials in the resin (Ella and Tongacan 1992).

\section{Wrapping/sealing of tapped portion using plastic}

As mentioned earlier, dirt like stones, soil, dried leaves, chipped wood, and bark lower the quality of the harvested resin. It was also noticed that in all the sites, a significant amount of resin had flowed and accumulated on the ground. To lessen dirt and wastage of the resin, some tappers in Gov. Generoso would attach, with wooden pegs, a clear plastic bag just beneath the cut as receptacle for the exuding resin, and then place another plastic sheet above the wound and the mouth of the bag. The same practice was reported in Brazil, where the collection of oleoresins from pine also uses plastic bags that are belted around the trunk (Rodrigues-Correa et al. 2013). Boschiero and Tomazello-Filho (2012) also stated that fixing a plastic bag by tying it around the trunk is a basic step in pine resin tapping. This is to minimize contamination of the resin by rainwater and other foreign materials. However, the use of plastic cover is not being practiced by all tappers in Gov. Generoso, as there are claims that the practice facilitates collection by illegal tappers and outsiders. In Palawan, tappers do not use any material to wrap and seal the tapped portion of the tree. They just leave the wound open, with resin exposed until it hardens, resulting in the accumulation of dirt on the resin. The Palawan tappers can harvest cleaner resin if they adopt the practice of the Gov. Generoso tappers.

\section{Post-tapping activities \\ Collection of resin}

The frequency of resin collection depends on many factors, such as tappers' needs, resin availability, and the weather. A whole variety of responses were given by the tappers from the three study sites on the frequency of their resin collection to include once a day, once or twice a week, once, twice or thrice a month, every after 45 days, once every two, every three months, etc. Razal et al. (2013) reported that Palawan resin gatherers do the harvesting once or twice a month.

All the tappers from the three study sites use a bolo to remove the hardened resin from the tree. Razal et al. (2013) earlier described that Palawan tappers scraped off resins from the bark using a sharp bolo. The use of a bolo does not always lead to the complete and clean separation of the resin from the tree. The hardened resin may be broken into small pieces, resulting in wastage or losses because the small fragments are usually left behind during collection. According to some experienced tappers in Palawan, they do not remove all of the resin from the wound and even allow some to fall to the ground and gather around the base of the tree to serve as a deterrent to termite attack (Razal et al. 2013). The terpenoids present in the resin may have combined chemical toxicity and repellency that render them capable of defense (Krokene 2015). Interestingly, the Palawan tappers devise their own environment-friendly containers to collect and transport the harvested resins. Tappers in Brooke's Point use a kayobong (Figure 5.A), which is made from kaong (Arenga pinnata) leaves and serves like an entrapment that prevents the resin from falling to the ground and being contaminated with dirt. Marufinas tappers in Puerto Princesa City collect the hardened resin with sarad (Figure 5.B), which is made of used rice sack and rattan.

To transport the resin from the collection site to their homes or the point-of-sale, tappers in Brooke's Point devised a bigger container called kiba (Figure 5.C) made of woven rattan stems and palm/kaong leaves, which can be carried on their backs and keeps the hands free for holding onto something as they descend from the mountains. They will carefully arrange and pack up to $60 \mathrm{kgs}$ of resin into the kiba, according to the size of the resin lumps. This exceeds the volume previously reported by Razal et al. (2013), which described a kiba that can carry about $40 \mathrm{kgs}$ of resin at a time. Likewise, Marufinas tappers improvise a container called rarong (Figure 5.D) made from rattan in transporting resin from the collection site to their respective storage areas. In Gov. Generoso, tappers use plastic bags or used sacks for collecting resin.
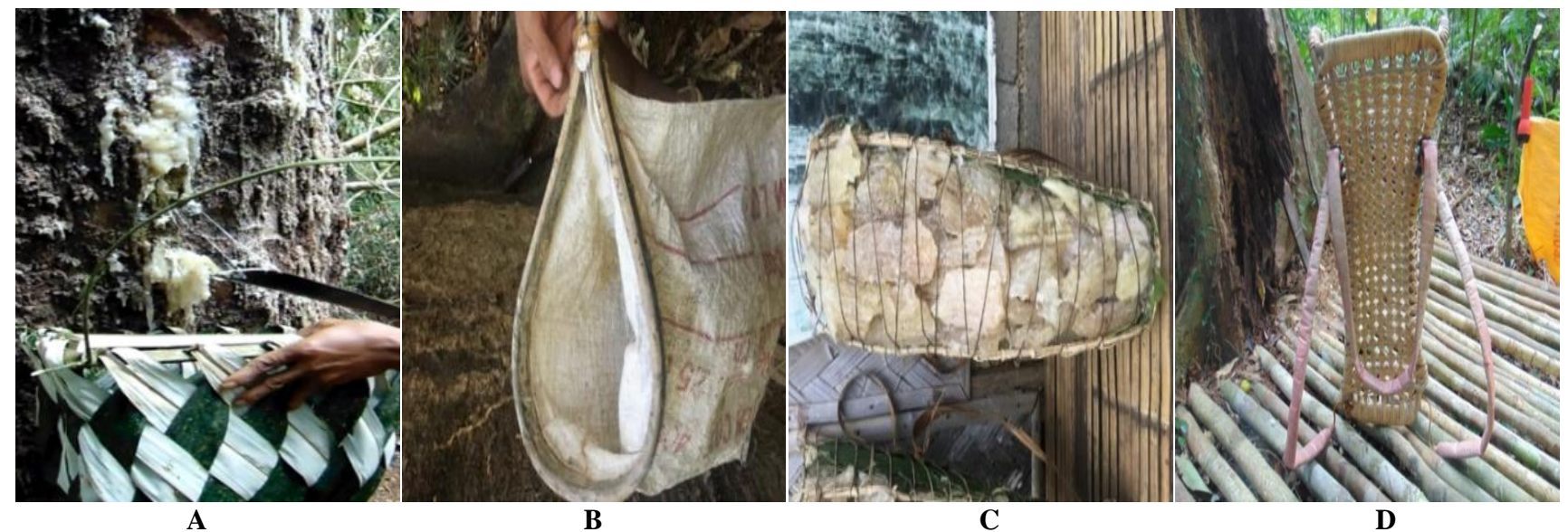

Figure 5. Post-tapping tools used by tappers of Brooke's Point and Puerto Princesa City, Philippines: A. Kayobong; B. Sarad; C. Kiba. and D. Rarong 


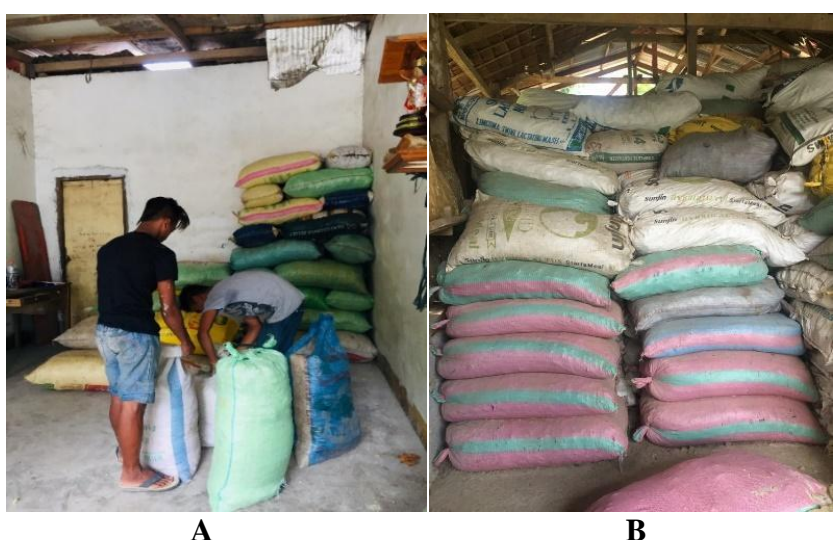

Figure 6. Governor Generoso's (A) and Brooke's Point's (B) bodega showing A. philippinensis resin stored in sacks

\section{Cleaning of resin}

Razal et al. (2013) described the resin cleaning process as one that involved the immersion of resins in water to allow the pieces of bark and other impurities to either float on the water surface or to settle at the bottom of the container. Afterward, the resins are chipped using sharp knives to remove unclean portions of the resin. In the present study, it was found that cleaning activities are not religiously practiced in the three study sites. When done, as in Gov. Generoso and Brooke's Point, tappers remove dirt from the resin by scraping them off with their bolo. This is usually performed at their houses before transporting the resin to the warehouse or the point-of-sale. Intact and clean resins command a better price. But for the tappers from Puerto Princesa City, the collected resin is sold as is. They do not perform resin cleaning since according to them, these practices do not lead to a higher selling price for the resin. In Java, Indonesia, instead of removing foreign matter and impurities from the collected resin, sieving and handpicking are being done (FAO 1995).

\section{Sorting of resin}

No uniform sorting and pricing scheme for the $A$. philippinensis resin was observed in the three sites. Pricing is not affected by the resin's physical properties in Gov. Generoso and is mainly dictated by the buyers. The resin is sold at PhP 20/kg (USD 0.39) regardless of size or color. It is worth noting that in Gov. Generoso, they perform solubility test using lacquer thinner to determine the resin class, especially when the resin being sold were sourced from new sites. Razal et al. (2013) reported that higher solubility means fewer insoluble materials (i.e., dirt, soil, bark) resulting in a higher recovery of the resin, a quality that is good for processing and suitability for export. As in Gov. Generoso, the price of resin is also dictated by the buyers in Puerto Princesa City, hence sorting of resin is hardly done. The resin is sold at PhP 18-20/kg (USD 0.360.40). In Brooke's Point, the classifier of the SBABP sorts the resin into three classes: tipak (PhP 30/kg or USD 0.59), class A (PhP 28/kg or USD 0.55 ) and class B (PhP 10/kg or USD 0.20) based on perceived resin "wholeness" and "cleanliness."
In the value chain study of A. philippinensis resin conducted by Razal et al. (2013), it was reported that in Palawan, the resin was usually sold to a kapatas or ahente at $\mathrm{PhP} 22.00$ per kilogram. The tappers are ensnared in an informal credit system or cash advance practice through the kapatas or ahente where the tappers could get "cash advance" or loan before the delivery of the resin. However, because the kapatas pays a low price for the resin and imposes high interest on the loan, this practice diminishes the tapper's net income (Razal et al. 2013). According to FAO (1995), in Indonesia, traded copal was distinguished by their hardness, color, size of the pieces as well as the state of cleanliness. Pale, clean pieces with high solubility in alcohol are of the best quality. They also reported that resin quality depends on the harvesting, cleaning, and handling practices; thus, it is important to improve these activities. Clean resin has always been considered by buyers and processors to be of good quality, thereby commanding higher demand and price. No further processing was carried out until the resin is formulated into finished products by the manufacturers. Subsequent processing being done by the end-users include heat treatment and dissolution in a suitable solvent (FAO 1995).

\section{Storage of resin}

In Gov. Generoso, the tappers sell the resin to designated buyers from within the respective barangays. The Municipal Tourism Officer, who doubles as resin consolidator, goes around the different barangays to collect the resins from the designated buyers to ensure there will be enough inventory for the next shipment. A warehouse (bodega) is maintained by the consolidator in the town proper which serves as storage area for the collected resin (Figure 6.A). There are laborers in the bodega who reweigh the resin using a 500-kg platform scale and repack them in 50 to $80-\mathrm{kg}$ sacks, being careful to keep them clean and solid.

Razal et al. (2013) reported that in Palawan, there was a warehouse or point-of-sale where the kapatas weighs, sorts, grades, and packs resins delivered by the tappers. These are still the same warehouse practices in Brooke's Point as observed in the current study (Figure 6.B). SBABP buys the resins from the tappers and maintains the warehouse. Puerto Princesa City tappers temporarily store their resin in an area of their choice before sales, unlike that being practiced in both Gov. Generoso and Brooke's Point.

The tapping practices, which are steeped in native traditions and cultural beliefs, have been passed on from generation to generation among the Pala'wan tappers. Some tappers also uphold their customary laws such as avoiding spitting and urinating on the A. philippinensis trees. Others would utter a prayer and perform rituals like offering eggs or planting a coin on the soil near the tree before tapping, believing that these will help increase resin yield. Spraying with sulfuric acid during tapping to stimulate resin flow was introduced by FPRDI-DOST (Ella and Tongacan 1992), but the tappers refused to adopt the method. They prefer the resin to flow naturally because there is no additional cost entailed and they consider it safer for the tapper, the trees, and the environment. 
In conclusion, the results of the study show that there are similarities and differences in the tapping and collection practices of $A$. philippinensis resin in different sites. But there are unique practices that were proven to be beneficial in some sites that may be worth replicating in the others to improve their A. philippinensis resin tapping and collection. Improved tapping helps boost indigenous peoples' incomes, sustain and protect the trees, and conserve biodiversity.

Tappers collect resins depending on their needs, availability, and season. The tappers agree that tapping resin as a livelihood is hard. The team's field visits confirmed the harrowing distances covered to reach the tapping sites, and in returning to the village centers while carrying the resin on their backs. For many households in the three study sites, tapping A. philippinensis resin is an alternative source of income, preferably done during the dry season when traversing the mountain is less difficult.

Future research undertakings on the following areas need to be conducted to further improve A. philippinensis resin production: (i) identification of higher-yielding varieties of A. philippinensis, (ii) determination of factors affecting resin yield and quality (iii) developing less damaging and high-yielding tapping methods, and (iv) mandating grading and pricing standards for $A$. philippinensis resin.

\section{ACKNOWLEDGEMENTS}

This work was supported by the Department of Science and Technology - Philippine Council for Agriculture, Aquatic, and Natural Resources Research and Development (DOST-PCAARRD) under the DOST Grantin-Aid Program. The authors are also grateful to all the tappers who willingly shared their knowledge and practices, and to the local partner organizations (LGU of Gov. Generoso, Davao Oriental, Nagkakaisang Tribu ng Palawan and Non-Timber Forest Products Exchange Programme (NTFP-EP) Philippines, and the Office of the Protected Area Superintendent of the Puerto Princesa Underground River) for their generous assistance.

\section{REFERENCES}

Boschiero FAT, Tomazello-Filho M. 2012. Anatomical aspects of resin canals and oleoresin production in pine trees. Resin: Biol Chem Appl 67-86. ISBN: 978-81-308-0493-4.

Davis RS, Hood S, Bentz BJ. 2012. Fire-injured ponderosa pine provides a pulsed resource for bark beetles. Can J For Res 42: 2022-2036. DOI: $10.1139 / x 2012-147$.

Frezza C, Venditti A, De Vita D, Toniolo C, Franceschin M, Ventrone A, Tomassini L, Foddai S, Guiso M, Nicoletti M, Bianco A, Serafini M. 2020. Phytochemistry, chemotaxonomy, and biological activities of the Araucariaceae family - A review. MDPI, Basel, Switzerland. Plants 9 (7), 888. DOI: 10.3390/plants9070888Licensee.

ERDB-DENR [Ecosystems Research and Development Bureau]. 2013. Compilation of selected forest species from Vol. 1 Nos. 1-10, 2013. Rise Information Series on Ecosystems (RISE) 25 (2 \& 3). Department of Environment and Natural Resources, Philippines.
Ella AB, Tongacan AL. 1992. Techniques in tapping almaciga (Agathis philippinensis Warb.) for sustained productivity of the tree: The Philippine experience. FPRDI J 2 (1\&2): 73-79.

Ella AB. 2000. Improved tapping of almaciga tree for sustained resin yield. Seminar proceedings: Harvesting of non-wood forest products. Joint FAO/ECE/ILO Committee on Forest Technology, Management, and Training. Menemen-izmir, Turkey.

FAO [Food and Agriculture Organization]. 1995. Gums, resins, and latexes of plant origin. Food and Agriculture Organization of the United Nations, Rome.

Hadiyane A, Sulistyawati E, Asharina W, Dungani R. 2015. A study on production of resin from Pinus merkusii Jungh. Et De Vriese in the Bosscha Observatory Area, West Java-Indonesia. Asian J Plant Sci 14 (2): 89-93.

Krokene P. 2015. Conifer defense and resistance to bark beetles. In: Vega FE, Hofstetter RW (eds) Bark Beetles: Biology and Ecology of Native and Invasive Species. Elsevier, New York.

Lai M, Dong L, Yi M, Sun S, Zhang Y, Fu L, Xu Z, Lei L, Leng C, Zhang L. 2017. Genetic variation, heritability and genotype $X$ environment interactions of resin yield, growth traits, and morphologic traits for Pinus elliottii at three progeny trials. Forests 8 (11), 409. DOI: 10.3390/f8110409.

Mordeno MC. 2019 August 7. Almaciga: Lighting up lives in Governor Generoso (Second Part). Minda news (This is our Mindanao). https://www.mindanews.com/special-reports/2019/08/almacigalighting-up-lives-in-governor-generoso-second-of-three-parts/

Perez D. 2014. Governance and leadership of the Pala'wan Tribe of Palawan, Philippines. Asia Pac J Educ Arts Sci 1 (5): 136-143.

Razal RA, Maralit AC, Colili NB, Alsa LN, Canlas RP. 2013. Value Chain Study for Almaciga resin. Non-Timber Forest Products Task Force.

Rodrigues-Correa K, De Lima J, Fett-Neto A. 2013. Pine oleoresin: tapping green chemicals, biofuels, food protection, and carbon sequestration from multipurpose trees. Food Energy Secur 1 (2): 81 93 DOI: $10.1002 / \mathrm{fes} 3.13$.

Rodríguez-García A, López R, Martín JA, Pinillos F, Gil L. 2014. Resin yield in Pinus pinaster is related to tree dendrometry, stand density and tapping-induced systemic changes in xylem anatomy. For Ecol Manag 313, 47-54. DOI: 10.1016/j.foreco.2013.10.038.

Samanta JN, Mandal K, Saravanan R, Gajbhiye N, Ravi, V. 2016. Influence of tapping position, intensity of tapping and season on gummosis of guggal (Commiphora wightii), oleo-gum-resin yield and quality. Indian J Agric Sci 86 (1): 143-146.

Seyfullah LJ, Beimforde C, Dal Corso J, Perrichot V, Rikkinen J, Schmidt AR. 2018. Production and preservation of resins - past and present. Biol Rev 93 (2018): 1684-1714. DOI: 10.1111/brv.12414.

Sharma SC, Prasad N, Pandey SK, Giri SK. 2018. Status of resin tapping and scope of improvement: A review. AMA, Agricultural Mechanization in Asia, Africa and Latin America 49: 16-26.

Sopsop LB, Buot, Jr. IE. 2011. Human-forest interaction in Aborlan Guba System, Palawan Island, Philippines: Implications for conservation and management. Asia Life Sci 20 (1): 153-171.

Susilowati A, Rachmat H. 2018. Growth and resin production structure of Pinus merkusii under different environment conditions (Case study in Perum Perhutani Seedling Seed Orchard). IOP Conf Ser Earth Environ Sci 209 (1): 012028. DOI: 10.1088/17551315/209/1/012028.

Tolera M, Menger D, Sass-Klaassen U, Sterck F, Copini P, Bongers F. 2013. Resin secretory structures of Boswellia papyrifera and implications for frankincense yield. Ann Bot 111 (1): 61-68. DOI: 10.1093/aob/mcs236.

Vermeer L, Bocxe K, Zuidema P, Sopsop L, Hoevenaars K, ReyesAntonio R. 2017. Effects of resin harvesting on the status of the Agathis philippinensis population in the Cleopatra's Needle Critical Habitat, the Philippines. Palawan Sci 9: 1-16.

Williams R, Nauman C, Zhu J. 2017. The effects of resin tapping on the radial growth of Masson pine trees in South China - A case study. $\begin{array}{lllll}\text { Agric } & \text { Res } & \text { Technol } 8 \text { (2) } & \text { 1-4. } & \text { DOI: }\end{array}$ 10.19080/ARTOAJ.2017.08.555732.

Zhao M, Liu C, Zheng G, Wei S, Hu Z. 2013. Comparative studies of bark structure, lacquer yield and urushiol content of cultivated Toxicodendron vernicifluum varieties. N Z J Bot 51 (1): 13-21. DOI: 10.1080/0028825X.2012.731005. 